\title{
PERBEDAAN HASIL BELAJAR PESERTA DIDIK BERDASARKAN GENDER PADA MATA PELAJARAN BIOLOGI
}

\author{
Novianti Muspiroh \\ Noviantimuspiroh.ak@gmail.com
}

Institut Agama Islam Negeri Syekh Nurjati Cirebon

- Received: 30 April 2020 •Accepted: 20 Mei 2020 •Published online: 30 Juni 2020

\begin{abstract}
Penelitian ini bertujuan untuk mengungkap sejauhmana perbedaan hasil belajar biologi siswa berdasarkan gender di MTsN 1 Kota Cirebon. Penelitian ini ialah penelitian kuantitatif ex post facto. Data hasil belajar siswa laki-laki dan perempuan dari dokumentasi guru. Populasi pada penelitian ini ialah seluruh siswa kelas 7 a MTsN 1 Kota Cirebon yang berjumlah 32 siswa. Berpijak pada hasil analisis data yang dilaksanakan dengan analisis variansi satu jalan dengan sel tidak sama didapatkan nilai $\mathrm{F}_{\text {hitung }}=2.270$ lebih besar dari $\mathrm{F}_{\text {tabel }}=1.97$, sehingga bisa disimpulkan ada perbedaan yang signifikan antara hasil belajar siswa berdasarkan gender di MTsN 1 Kota Cirebon. Selanjutnya dilaksanakan uji simple effect antar hasil belajar siswa laki-laki dan siswa perempuan untuk mengetahui manakah yang lebih baik antara hasil belajar siswa lakilaki ataukah siswa perempuan. Dari uji tersebut didapatkan nilai $F_{\text {hitung }}$ memperlihatkan perbedaan yang signifikan, yakni $F_{\text {hitung }}=2.597$ lebih besar dari $F_{\text {tabel }}=1.97$. Oleh karena itu, bisa disimpulkan bahwa hasil belajar siswa perempuan lebih baik dari pada siswa laki-laki di MTsN 1 Kota Cirebon.
\end{abstract}

Kata kunci: Hasil Belajar, Gender, Mata Pelajaran Biologi..

\section{Abstract}

This study aimed to reveal the extent of differences in student biology learning outcomes based on gender in State Islamic Junior School 1 Kota Cirebon. This research was an ex post facto quantitative research. Data of learning outcomes of male and female students was from teacher documentation. The population in this study was all 7 th grade students of State Islamic Junior School 1 Cirebon City, which were 48 students. Based on the results of data analysis carried out by one-way analysis of variance with unequal cells, the value of $F_{\text {count }}=2.270$ is greater than $F_{\text {table }}=1.97$, so it could be concluded that there were significant differences between student learning achievement by gender in State Islamic Junior High School 1 Kota Cirebon. A simple effect test was conducted between the learning achievement of male and female students to find out which was better between the learning achievement of male students or female students. From this test, it was found that the $\mathrm{F}_{\text {count }}$ value showed a significant difference, ie $\mathrm{F}_{\text {count }}=2.597$ greater than $\mathrm{F}_{\text {table }}=$ 1.97. Therefore, it could be concluded that the learning achievement of female students are better than male students in State Islamic Junior School 1 Cirebon City

Keywords: Learning Achievement, Gender, Biology Subjects. 
Novianti Muspiroh

\section{A. PENDAHULUAN}

Dari perspektif pembelajaran, gender tampaknya memainkan peran penting. Peran tersebut memainkan peran penting dalam motivasi, sikap, dan prestasi belajar siswa (Dayroglu \& Asik, 2004). Sekolah harus memberi kesempatan yang sama kepada semua siswa tanpa membeda-bedakan gender agar tidak terjadi diskriminasi. Dalam institusi pendidikan terkadang siswa mengikuti aktivitas pembelajaran di kelas antara laki-laki dan perempuan dipisahkan dalam kelas berbeda. Proses pembelajaran dipisah berdasarkan gender. Hal tersebut akan terjadi gep antara laki-laki dan perempuan, dan juga berdampak terhadap pemahaman serta hasil belajar. Walaupun begitu sampai sekarang diskriminasi kesempatan pendidikan bagi laki-laki masih terjadi dalam dunia pendidikan. Pendidikan bagi seluruh orang masih adalah suatu harapan yang masih jauh dari fakta yang ada. Diskriminasi gender dalam dunia pendidikan tidak hanya terjadi di Indonesia, namun pula terjadi di berbagai negara (Suyanto, 2010:65).

Adanya diskriminasi antara laki-laki dan perempuan hampir dalam sejumlah bidang, diantara bidang pendidikan. Dalam dunia pendidikan persoalan gender adalah dampak secara tidak langsung dari kultur patriarki yang hidup di masyarakat. Budaya patriarki membedakan peran dan posisi laki-laki dan perempuan. Perbedaan peran dan posisi dan peran tersebut juga mengakibatkan perbedaan prestasi akademik antara lakilaki dan perempuan. Dunia pendidikan yang tambah berkembang menuntut semua orang untuk bisa berprestasi dengan optimal. Prestasi akademik yang baik menjadi patokan kesuksesan seorang siswa. Prestasi akademik yang baik dapat diperoleh apabila siswa dapat mengatasi berbagai faktor yang mempengaruhi prestasinya (Saleh, 2011:2$3)$.

Perbedaan gender juga memainkan peran penting dalam mendapatkan pendidikan. Biasanya, di negara-negara ekonomi rendah atau negara-negara dunia ketiga kurang memperhatikan pendidikan wanita. Secara bertahap, langkah-langkah seperti itu telah diambil terhadap ketidakadilan sehingga sekarang pendidikan untuk perempuan juga menjadi sama pentingnya (Khan, Nawaz, Chaudhry, Hyder, \& Butt, 2012: 798-801). Perbedaan gender yang serupa sekarang telah menciptakan sebuah pola yang sekarang telah menjadi kontradiksi. Untuk menjelaskan dan pola itu didefinisikan sebagai nilai yang baik telah diambil oleh siswa perempuan lebih dari laki-laki.

Dalam hal gender ini, acapkali kaum perempuan yang paling dirugikan. Peran perempuan acapkali diremehkan di dalam banyak bidang, khususnya di dalam bidang pendidikan. Persoalan gender dalam pendidikan adalah diantara masalah yang sangat 
Nama penulis

krusial. Kaum perempuan dinilai tidak begitu penting dan tidak harus mengenyam pendidikan yang tinggi. Begitu pula di dalam bidang lainnya. Laki-laki yang lebih diutamakan di dalam berbagai bidang. Padahal sebenarnya pendidikan itu sangat penting untuk pertumbuhan dan perkembangan umat manusia yang tidak membedakan apakah laki-laki ataupun perempuan, semuanya sama-sama membutuhkan pendidikan.

Perbedaan hasil berlajar dalam pandangan gender dalam pendidikan acapkali diteliti oleh sejumlah peneliti di banyak negara termasuk di Tanah Air. Hasil penelitian yang dilaksanakan oleh Siti Khaidah dan Ab Manan, et al, (2003), yang berjudul "Kajian tentang Pencapaian Akademik Pelajar-Pelajar di UiTM Shah Alam: Satu Analisa Perbandingan Antara Jantina." Hasil penelitiannya memperlihatkan bahwa prestasi akademik mahasiswa perempuan lebih baik apabila dibandingkan dengan mahasiswa laki-laki (Saleh, 2011:18). Akan tetapi hasil berbeda dari penelitian Odagboyi Isaiah Amedu (2015:176-179) Analisis t-test menunjukkan bahwa tidak ada perbedaan yang signifikan antara skor rata-rata siswa laki-laki dan perempuan. Kelas diajarkan, topik dalam mikroorganisme selama 12 minggu. Pada akhir 12 minggu, BAT diberikan sebagai posttest. Hasilnya dianalisis menggunakan uji-t pada tingkat signifikansi 0,05 . Hasil menunjukkan bahwa ada perbedaan yang signifikan antara skor rata-rata mendukung laki-laki. Ini menunjukkan bahwa siswa laki-laki mendapatkan lebih banyak dari metode jigsaw dibandingkan dengan siswa perempuan.

Sejumlah riset untuk mengkaji bagaimana gender berhubungan dengan pembelajaran matematika, laki-laki dan perempuan dibandingkan dengan menggunakan berbagai variabel termasuk kemampuan kinerja, bakat, bawaan, motivasi, dan sikap. Sejumlah penelitian meyakini bahwa pengaruhi faktor jenis kelamin dalam matematika ialah disebabkan terdapatnya perbedaan biologis dalam otak siswa laki-laki dan perempuan yang terungkap melalui pengamatan, bahwa siswa perempuan, secara umum, lebih unggul dalam bidang bahasa dan menulis, sedangkan siswa laki-laki lebih unggul dalam bidang matematika sebab sejumlah kemampuan ruangnya yang lebih baik. Dampaknya, perbedaan gender dalam matematika sangat sukar untuk diubah. Di bawah ini peneliti sajikan perbedaan karakteristik gender, yaitu (1) secara fisik, mayoritas perempuan lebih cepat matang jika dibandingkan dengan laki-laki, meskipun laki-laki lebih kuat dan besar. (2) Kemampuan spasial kemampuan laki-laki memperlihatkan sejumlah masalah bahasa yang lebih baik dibandingkan perempuan. Walaupun begitu perempuan lebih baik dalam mengerjakan berbagai tugas verbal di tahun-tahun awal dan bisa dipertahankan. (3) Laki-laki lebih superior dalam kemampuan matemikan dan 
berlanjut pada masa sekolah. (4) Kemampuan laki-laki dalam sains memperlihatkan superioritas ketika di sekolah menengah atas. (5) Dalam kaitannya dengan pelaksanaan tugas-tugas maskulin, laki-laki lebih baik daripada perempuan. (6) Laki-laki mempunyai pembawaan lebih agresif jika dibandingkan perempuan (Saraswati, 2015).

Berlandaskan penelitian pendahuluan peneliti menemukan banyak peserta didik perempuan jauh lebih banyak dari pada jumlah peserta didik laki-laki di Madrasah Tsanawiyah Negeri 1 Cirebon. Selanjutnya melihat dari perolehan peringkat, memperlihatkan terdapat kecenderungan bahwa peserta didik perempuan mengungguli perolehan peringkat 1-10. Dalam proses pembelajaran umumnya peserta didik perempuan lebih aktif secara verbal.

Walaupun dalam penelitian yang lain atau sebelumnya menjelaskan bahwa IQ perempuan berada lima poin lebih rendah daripada IQ laki-laki. Akan tetapi, berdasarkan penelitian terbaru memperlihatkan bahwa selisih IQ perempuan dan lakilaki semakin berkurang tahun-tahun belakangan ini. Sebagaimana dinyatakan oleh ahli penguji IQ kenamaan dunia, James Flynn dan Casé, mempublikasikan temuan menarik tentang level kecerdasan antara laki-laki dan perempuan. Flynn menjelaskan bahwa IQ perempuan sekarang ini lebih tinggi dibandingkan laki-laki. Mengapa demikian? Sederhana saja, perempuan dapat melaksanakan banyak hal atau tugas. Dalam 100 tahun terakhir, Flynn penjelasan bahwa IQ perempuan memang tertinggal kurang lebih 5 poin dibandingkan laki-laki. Akan tetapi, sekarang ini gep tersebut terhapus dan perempuan memimpin di depan. Maka, temuan ini memutarbalikkan perdebatan gender yang acapkali memposisikan laki-laki sebagai pemimpin dalam uji IQ. Berdasarkan hasil penelitian tersebut, menunjukkan bahwa terjadi perubahan level IQ atau kecerdasan siswa laki-laki dan perempuan, pada mulanya IQ siswa laki-laki lebih tinggi jika dibandingkan dengan IQ siswa perempuan, namun saat ini yang terjadi malah sebaliknya. Perubahan tersebut yang menunjukkan bahwa kesetaraan gender sudah terjadi (Flynn dan Casé, 2011:799-803).

Peneliti dan pendidik telah mencoba beberapa pendekatan untuk menjelaskan kontradiksi tersebut di atas yang tampaknya telah diamati antara kedua gender dan perbedaan dalam pencapaian. Berbagai penelitian telah dilakukan pada topik dan telah dilaporkan bahwa nilai sekolah memberikan dampak signifikan pada keterampilan belajar siswa (baik itu laki-laki atau perempuan). Kelas juga mencerminkan perilaku siswa dalam konteks sosial di dalam kelas. Tanda-tanda yang didapat siswa di ruang kelas, meskipun membutuhkan banyak upaya tetapi hal itu mempengaruhi siswa untuk 
Nama penulis

jangka waktu yang lebih lama. Di sisi lain, dalam beberapa jenis tes standar digunakan untuk menilai kemampuan khusus dan kemampuan kritis siswa (terlepas dari jenis kelaminnya) menghilangkan pengaruh masyarakat. Peneliti lain juga telah menguraikan beberapa faktor yang digunakan untuk membuat beberapa membedakan antara nilai sekolah dan prestasi yang diperoleh seorang siswa. Faktor-faktor yang telah dimasukkan oleh para peneliti dalam penelitian ini adalah kemampuan belajar, bersama dengan tingkat pengenalan dengan tes, tingkat kepercayaan, dan tingkat kecemasan juga memberikan dampak signifikan pada kinerja siswa menghilangkan faktor gender. (Yau \& Cheng, 2012).

Berangkat dari permasalahan tersebut, maka peneliti mencoba untuk melaksanakan penelitian yang berjudul Perbedaan Hasil Belajar Peserta Didik Berdasarkan Gender Pada Mata Pelajaran Biologi di MTsN 1 Kota Cirebon

\section{B. METODOLOGI PENELITIAN}

Penelitian ini bertempat di Madrasah Tsanawiyah Negeri 1 Cirebon. Penelitian ini adalah penelitian kuantitatif dengan memakai metode ex post facto. Arti ex post facto, yakni dari apa dilakukan sesudah terjadi kenyataan, maka penelitian ini acapkali dinamakan sebagai penelitian setelah kejadian. Penelitian ini juga acapkali dinamakan after the fact atau setelah fakta dan ada pula peneliti yang menyebutnya sebagai penelitian penelusuran kembali (Kurniawan, 2018:19). Dalam penelitian ini peneliti tidak memberi perlakuan berupa mengajar seperti umumnya yang dilaksanakan peneliti pendidikan lainnya, sebab sejalan dengan jenis penelitian, yaitu ex post facto, perlakuan yang dilaksanakan oleh orang lain (guru) yang sudah berlalu), peneliti hanya menggambil data sampel yang sudah ada, yaitu ujian semester mata pelajaran biologi.

Penelitian ini dilaksanakan di Madrasah Tsanawiyah Negeri 1 Kota Cirebon yang beralamat di Jl. Pilang Raya Nomor 38, Kelurahan Sukapura, Kecamatan Kejaksan, Kota Cirebon, Jawa Barat dari 29 November 2019 sampai 3 Januari 2020. Penelitian ini adalah penelitian populasi secara kluster pada kelas 7 a yang terdiri dari 22 siswa perempuan dan 10 siswa laki-laki.

Tehnik pengumpulan data menggunakan observasi non partisipan terhadap kondisi pembelajaran siswa. Selanjutnya penulis menggunakan wawancara untuk mengungkap data motivasi dan kegiatan siswa dalam pembelajaran biologi. Disamping itu, penulis menggunakan studi dokumentasi, yaitu berupa ujian akhir semester mata pelajaran biologi. Data dari berbagai tehnik pengumpulan tersebut dipergunakan untuk mengungkap perbandingan hasil belajar biologi peserta didik berdasarkan gender. 
Peneliti melakukan uji prasyarat analisis melalui uji normalitas dan uji homogenitas. Uji normalitas dipakai untuk mengungkap apakah populasi berdistribusi normal atau tidak. Dalam rangka uji normalitas yang dipakai ialah uji Liliefors. Adapun kesimpulan dari uji normalitas ialah apabila $\mathrm{H}_{0}$ ditolak, maka populasi tidak berdistribusi normal dan apabila $\mathrm{H}_{\mathrm{o}}$ diterima, maka populasi berdistribusi normal atau $\mathrm{H}_{\mathrm{o}}$ ditolak, apabila LDK dan $\mathrm{H}_{\mathrm{o}}$ diterima, apabila L $\notin D K$. Uji Homogenitas dilaksanakan untuk mengungkap apakah sejumlah variansi dari sejumlah populasi sama atau tidak dinamakan uji homogenitas variansi populasi. Uji homogenitas memakai uji Bartlett dengan kesimpulan $\mathrm{H}_{\mathrm{o}}$ ditolak apabila ? 2 ? DK (Budiyono, 2013). Formula yang dipakai ialah analisis varian satu jalur (ANAVA klasifikasi tunggal $=$ ANAVA). Kriteria pengujian ialah jika $\mathrm{F}_{\text {hitung }}$ lebih kecil atau sama dengan $\mathrm{F}_{\text {tabel }}$ pada tarap error $5 \%$ maka $\mathrm{H}_{\mathrm{o}}$ diterima dan sebaliknya jika $F_{\text {hitung }}$ lebih besar $(>)$ dengan $F_{\text {tabel }}$ pada tarap error $5 \%$, maka $\mathrm{H}_{\mathrm{o}}$ ditolak atau $\mathrm{H}_{1}$ diterima. Kemudian apabila harga $\mathrm{F}$ signifikan, diteruskan dengan uji simple effect antar sel dengan formula F-Sceffe untuk mengungkap perbedaan atau perbandingan hasil belajar peserta didik berdasarkan gender.

\section{TEMUAN DAN PEMBAHASAN}

Bagian ini sebelum menganalisis data memakai formula analisis varians satu jalan terlebih dahulu dilaksanakan uji prasyarat analisis. Uji prasyarat analisis yang dilaksanakan ialah uji normalitas dan homogenitas terhadap hasil belajar biologi peserta didik baik laki-laki ataupun perempuan. Hal tersebut dilaksanakan guna mengetahui apakah seluruh data yang hendak dianalisis berdistribusi normal atau tidak dan dalam kondisi homogen atau tidak.

Uji normalitas terhadap populasi dalam studi ini dilaksanakan sebanyak dua kali, yakni pada hasil belajar peserta didik perempuan, dan pada hasil belajar peserta didik laki-laki. Untuk mengetahui apakah setiap populasi berdistribusi normal ataukah tidak. Uji normalitas populasi dilaksanakan untuk semua kelompok memakai metode Lilliefors. Hasil normalitas dapat dilihat dalam tabel di bawah ini:

Tabel 1

Hasil Uji Normalitas Populasi terhadap Data Prestasi Mata Pelajaran Biologi Peserta Didik Laki-laki dan Perempuan

\begin{tabular}{|l|c|c|c|c|c|}
\hline Kelompok & $\boldsymbol{n}$ & $\boldsymbol{L}_{\text {obs }}$ & $\boldsymbol{L}_{\mathbf{0 , 0 5} \boldsymbol{n} \boldsymbol{n}}$ & Keputusa Uji & Simpulan \\
\hline Laki-laki & 10 & 0,0830 & 0,191 & $\mathrm{H}_{\mathrm{o}}$ diterima & Normal \\
\hline Perempuan & 22 & 0,0920 & 0,174 & $\mathrm{H}_{\mathrm{o}}$ diterima & Normal \\
\hline
\end{tabular}


Dari tabel tersebut bisa ditinjau hasil uji normalitas populasi terhadap data hasil belajar peserta didik ataupun peserta didik perempuan. Kedua uji normalitas tersebut memiliki nilai $L_{o b s}$ kurang dari $L_{0,05 ; n}$, karena $L_{o b s}$ ?DK. Hal ini bermakna normalitas populasi ialah $\mathrm{H}_{\mathrm{o}}$ diterima, sehingga didapatkan kesimpulan bahwa seluruh populasi berdistribusi normal, kemudian dilaksanakan uji homogenitas variansi populasi untuk mengungkap apakah sejumlah populasi yang dibandingkan memiliki variansi yang sama atau tidak. Uji homogenitas variansi populasi ini dilaksanakan sebanyak satu kali, yaitu dengan membandingkan variansi hasil belajar biologi peserta didik laki-laki dan hasil belajar biologi peserta didik perempuan. Berpijak pada hasil uji homogenitas variansi populasi terhadap data tersebut, didapatkan nilai ? 22 obs sejumlah $-5,1243$,

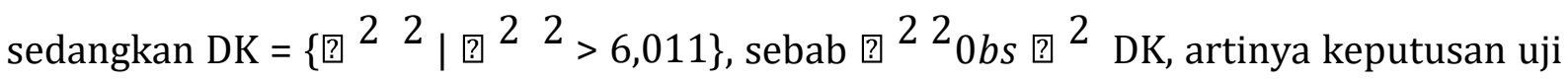
homogenitas variansi populasi ialah $\mathrm{H}_{\mathrm{o}}$ diterima.

Dari hasil perhitungan tersebut didapatkan simpulan bahwa sejumlah populasi yang dibandingkan memiliki variansi yang homogen (sama). Berpijak hasil uji hipotesis yang sudah dilaksanakan dengan uji anava satu jalan didapatkan nilai $\mathrm{F}_{\text {hitung }}=2.270$ dan $\mathrm{F}$ tabel $=1.97$ pada tingkat signifikasi 5\% sehingga dapat kita lihat bahwa $F_{\text {hitung }}$ lebih kecil daripada $\mathrm{F}_{\text {tabel. }}$. Hal tersebut bisa dilihat pada tabel rangkuman hasil analisis anava satu jalan sebagai berikut:

Tabel 2

Hasil Analisis Anava Satu Jalan

\begin{tabular}{|lllcccl|}
\hline Sumber & JK & D & RK & $\mathrm{F}_{\mathrm{h}}$ & \\
\hline Variasi & & & & & $5 \%$ & Uji \\
\hline Antar A & 399,1 & 1 & 399,1 & 2.290 & 1.97 & $\mathrm{H}_{\mathrm{o}}$ ditolak \\
\hline Galat & 8218,9 & 46 & 180.1 & - & - & \\
\hline Total & 8705.1 & 49 & - & - & - & \\
\hline
\end{tabular}

Dari tabel tersebut terlihat bahwa ada perbedaan yang signifikan antara hasil belajar peserta didik laki-laki dan peserta didik perempuan. Hal tersebut dapat ditinjau dari $\mathrm{F}_{\text {hitung }}=2.290>\mathrm{F}_{\text {tabel }}=1.97 \mathrm{H}_{\mathrm{o}}$ ditolak. Kemudian dilaksanakan uji simple effect antar hasil belajar peserta didik laki-laki dan peserta didik perempuan. Dari uji tersebut didapatkan nilai $F_{\text {hitung }}$ memperlihatkan perbedaan yang signifikan, yakni $F_{\text {hitung }}=2.597>\mathrm{F}_{\text {tabel }}$ =1.97. Oleh karena itu, maka dilaksanakan perbandingan nilai rata-rata hasil belajar peserta didik laki-laki dan perempuan. Perbandingan hasil belajar peserta didik laki-laki dan perempuan menunjukkan nilai rata-rata peserta didik perempuan 79.21 dan 
Novianti Muspiroh

peserta didik laki-laki 65.40. Hasil uji hipotesis tersebut sejalan dengan hasil observasi yang berkali-kali dilaksanakan oleh peneliti di dalam kelas saat proses pembelajaran berlangsung pada bulan Desember 2019 terlihat bahwa peserta didik perempuan lebih termotivasi dan aktif mengikuti proses pembelajaran dibandingkan dengan peserta didik laki-laki. Sebagian besar peserta didik laki-laki lebih banyak bergurau atau mengganggu teman-temannya yang sedang mengerjakan tugas. Mereka kurang memiliki perhatian terhadap penjelasan guru ketika menyampaikan materi di depan kelas. Kondisi ini diamini oleh beberapa guru mata pelajaran biologi bahwa memang banyak siswa laki-laki yang kurang termotivasi dalam mengikuti pembelajaran, dan kurang mengerjakan tugas-tugas atau latihan-latihan yang diberikan secara maksimal. Ditegaskan pula oleh wakil kepala madrasah bagian kurikulum yang mengatakan bahwa pada umumnya para siswa perempuan lebih tekun dalam belajar dan patuh pada tata tertib sekolah. Hal inilah diantara faktor rata-rata siswa perempuan prestasi belajarnya lebih baik.

Temuan di atas dipertegas oleh hasil penelitian Khaleel (2017:378) yang mengatakan bahwa siswa perempuan cenderung lebih peduli tentang studi dan mereka bekerja lebih keras daripada siswa laki-laki. Anak laki-laki lebih tertarik pada teknologi daripada anak perempuan karena mereka selalu menjelajahi komputer dan bermain video game dan mereka lebih mengandalkan teknologi daripada anak perempuan. Pasti ada solusi yang dapat membuat kedua jenis kelamin pada tingkat akademis yang sama seperti memasukkan lebih banyak teknologi dalam belajar dan termasuk pekerjaan yang lebih praktis di bidang akademik.

Beberapa jenis penelitian telah dilakukan pada topik perbandingan antara kinerja siswa amale dan siswa perempuan. Siswa perempuan ditemukan baik di kelas daripada siswa laki-laki. Siswa perempuan diklaim memiliki keterampilan belajar yang lebih baik dibandingkan dengan anak laki-laki (Unity, 2015: 101-106; O’Dea, 2018).

Siswa perempuan (terlepas dari latar belakang pendidikan) ditemukan lebih aktif di bidang akademik daripada siswa laki-laki (Ekonom, 2015). Ini adalah fakta bahwa siswa laki-laki memiliki banyak pengetahuan tentang dunia teknis dan tingkat kecerdasan mereka sama sekali berbeda dari perempuan tetapi tetap saja, perbedaan antara nilainilai itu sama dan masih pada posisinya. Nilai-nilai di bidang akademik (baik siswa yang berasal dari salah satu lembaga pendidikan atau beberapa tahap pendidikan lainnya) telah menciptakan pola khas bahwa siswa perempuan lebih baik jika dibandingkan dengan siswa laki-laki (Coskun, 2014). 
Nama penulis

Beberapa faktor digunakan untuk investigasi studi masing-masing seperti tingkat kepercayaan siswa, tingkat formalitas dengan tes, pemanfaatan teknologi, dan lain-lain (Brown, 2015). Siswa laki-laki diklaim memiliki keterampilan analitis yang jauh lebih baik daripada siswa perempuan dan dalam kegiatan yang terkait dengan pemanfaatan atau penggunaan beberapa teknologi canggih, siswa laki-laki ditemukan memiliki kinerja yang lebih baik, meninggalkan siswa perempuan di belakang dalam skor. Namun, ketika titik penelitian datang ke kegiatan yang terkait dengan akademisi murni maka, dalam hal ini siswa perempuan ditemukan berkinerja lebih baik daripada siswa laki-laki. Di bidang akademik, siswa perempuan diamati mendapatkan nilai yang lebih baik daripada siswa laki-laki. Tingkat kepercayaan siswa perempuan yang kurang dalam penggunaan teknologi ditemukan dominan pada tes akademik. Di sisi lain, siswa lakilaki lebih menikmati penggunaan dan pemanfaatan teknologi untuk studi dibandingkan dengan siswa perempuan (Gnaultati, 2014).

\section{KESIMPULAN}

Berpijak pada hasil penelitian dan pembahasan, maka bisa disimpulkan bahwa hasil uji hipotesis memperlihatkan nilai $\mathrm{F}_{\text {hitung }}=2.270$ dan $\mathrm{F}_{\text {tabel }}=1.97$ pada taraf signifikasi $5 \%$ sehingga dapat dilihat bahwa $F_{\text {hitung }}$ lebih kecil daripada $F_{\text {tabel }}$ sehingga bisa dinilai bahwa ada perbedaan hasil belajar biologi yang signifikan antara peserta didik laki-laki dan peserta didik perempuan di Madrasah Tsanawiyah Negeri 1 Kota Cirebon. Kemudian dilaksanakan uji simple effect antar hasil belajar siswa laki-laki dan siswa perempuan. Dari uji tersebut didapatkan nilai $F_{\text {hitung }}$ memperlihatkan perbedaan yang signifikan, yakni $\mathrm{F}_{\text {hitung }}=2.597>\mathrm{F}_{\text {tabel }}=1.97$. Oleh karena itu, maka bisa disimpulkan hasil belajar siswa perempuan lebih baik daripada siswa laki-laki.

\section{REFERENCES}

Amedu, Odagboyi Isaiah. 2015. "The Effect of Gender on the Achievement of Students in Biology Using the Jigsaw Method". Journal of Education and Practice, 6 (17), 176-179.

Brown, D. G. 2015. Study Shows Girls Get Better Grades For The Same Work As Boys. (online) tersedia: http://www.returnofkings.com/75159/study-showsgirls-get-better-grades-for-the-same-work-as-boys Diakses 6 Desember 2019.

Budiyono. 2013. Statistika Untuk Penelitian. Edisi Ke-3, Surakarta: UNS Press.

Coskun, L. 2014. "The Girls are Better at Language Learning: A Comparative Approach". Journal of Educational and Social Research, 4 (2), 17-21. doi:Doi:10.5901/jesr.2014.v4n2p17 
Dayroglu, M., \& Asik, S. T. 2004. Gender Differences in Academic Performance in a Large Public University in Turkey. Ankara: Middle East Technical University.

Economist. 2015. Why Girls do Better at School than Boys. (online) tersedia: http://www.economist.com/blogs/economist-explains/2015/03/economistexplains-3 diakses 4 Desember 2019.

Flynn, James, Lilia Rossi-Casé. 2011. “Modern Women Match Men on Raven's Progressive Matrices". Personality and Individual Differences, 50 (6), 799-803.

Gnaultati, E. 2014. Why Girls Tend to Get Better Grades Than Boys Do. (online) tersedia: http://www.theatlantic.com/education/archive/2014/09/why-girlsget-better-grades-than-boys-do/380318/ diakses 6 Desember 2019.

Khaleel, Mousa. 2017. "Female Students are more likely to get Higher Grades than Male Students". International Journal of Scientific and Research Publications, 7 (3), 378-386.

Khan, B. B., Nawaz, R., Chaudhry, K. M., Hyder, A. U., \& Butt, T. M. 2012. "Evaluation of Comparitive Academic Performance of undergraduate Students at University Level". The Journal of Animal \& Plant Sciences, 22 (3), 798-801.

Kurniawan, Asep. 2018. Metodologi Penelitian Pendidikan. Bandung: Remaja Rosdakarya.

O’Dea, R. E., M. Lagisz, M. D. Jennions, and S. Nakagawa. 2018. “Gender Differences in Individual Variation in Academic Grades Fail to Fit Expected Patterns for STEM". Nature Communications, 9, 3777.

Saleh, Minhayati. 2011. Perbedaan Gender dalam Prestasi Akademik Alumni Tadris. Semarang: Kementerian Agama Institut Agama Islam Negeri Walisongo.

Saraswati, Enggar. 2015. Perbedaan Hasil Belajar Siswa Laki-laki dan dalam Mata Pelajaran Matematika kelas III semester 2 Materi Sudut dan Pecahan di SD Negeri seDesa Caturharjo, Kecematan Sleman Kabupaten Sleman. Yogyakarta: Fak. Ilmu Pendidikan Universitas Negeri Yongyakarta.

Suyanto, Joko. 2010. Gender dan Sosialisasi. Jakarta: Nobel Edumedia.

Unity, O. 2015. "Influence of Gender on Students' Academic Achievement in Government Subject in Public Secondary Schools in Oredo Local Government Area of Edo State, Nigeria". Journal of Educational and Social Research, 5 (2), 101106.

Vina. Penelitian: IQ Perempuan lebih Tinggi Dibandingkan IQ Laki-laki. https:// www.ipotnews.com/index.php?jdl=PenelitianIQ_Perempuan_Lebih_T inggi_Dibandingkan_IQ_Laki_laki\&level2=newsandopini on\&id=1465825\&img=level1_highli ghts_4. Diakses 05 Desember 2019.

Yau, H. K., \& Cheng, A. L. 2012. "Gender Difference of Confidence in Using Technology for Learning". The Journal of Technology, 38 (2), 74-79. 